\title{
THE ASSOCIATION BETWEEN POOR GLYCAEMIC CONTROL (HBA1C LEVELS $\geq 7 \%$ ) AND HIGHER INCIDENCE OF DIABETIC RETINOPATHY IN SMALL GROUP OF TYPE 2 DIABETES MELLITUS PATIENTS ATTENDING MAHATMA GANDHI MEMORIAL GOVERNMENT HOSPITAL, TRICHY
}

\author{
Vijayalakshmi Sigamani ${ }^{1}$, Nirmala Devi Kanagaraj², Vijayabharathi Kuppuswamy Rajagantham ${ }^{3}$
}

${ }^{1}$ Assistant Professor, Department of Biochemistry, KAPV Government Medical College (MGMGH), Trichy.

2Professor \& HOD, Department of Biochemistry, KAPV Government Medical College (MGMGH), Trichy.

${ }^{3}$ Associate Professor, Department of Ophthalmology, MGMGH, Trichy.

\section{ABSTRACT}

\section{BACKGROUND}

Diabetes mellitus is prevalent worldwide. Lot of research work has been done and published on Diabetes Mellitus and its long-term complications. But studies related to the control of diabetes mellitus and its duration with respect to the onset and severity of its microvascular complications are not widely conducted in India. This study was taken up to study the causal relationship between the control (based on $\mathrm{HbA}_{1 \mathrm{c}}$ levels; $\mathrm{HbA}_{1 \mathrm{c}} \geq 7 \%$ is considered as poor glycaemic control) and the onset of complications.

\section{MATERIALS AND METHODS}

It is a case-control study with a total of 60 subjects. Cases were Type 2 DM Patients with Diabetic Retinopathy (DR) and Controls were Type 2 DM without signs suggestive of DR. Subjects were selected based on self-answered research questionnaire and then a careful fundal examination. A total of 31 cases and 29 control subjects were included in this study. Poor Glycaemic Control (HbA $\mathrm{H}_{1 \mathrm{c}}$ levels $\geq 7 \%$ ) was taken as Exposure Factor. HbA1C levels was assayed in every subject using HemoCue Analyser using Column Cartridges (Boronate Affinity Chromatography). After collecting the data, the statistical analysis was done by calculating the Odd's Ratio using MedCalc easy to use statistical software.

\section{RESULTS}

Out of the 31 cases, poor glycaemic control was present in 25 subjects and absent in 6 subjects. Out of the 29 Controls, poor glycaemic control was present in 18 and absent in 11. The significance of association between Poor Glycaemic Control and DR was assessed by calculation of Odd's ratio (using MedCalc Easy-to-use Statistical Software) at 95\% Confidence Interval and with a pvalue 0.05 , the Confidence levels (lower and higher values) was got and statistical interpretation done. Odds ratio was 2.75 which shows significant association between poor Glycaemic control of Diabetes (high $\mathrm{HbA}_{1 \mathrm{c}}$ levels) and presence of complications (Diabetic Retinopathy).

\section{CONCLUSION}

It is concluded that there is a strong association between poor Glycaemic Control $\left(\mathrm{HbA}_{1 \mathrm{c}} \geq 7 \%\right)$ and higher incidence of Diabetic Retinopathy.

\section{KEYWORDS}

Diabetes Mellitus, Diabetic Retinopathy, $\mathrm{HbA}_{1 \mathrm{c}}$.

HOW TO CITE THIS ARTICLE: Sigamani V, Kanagaraj ND, Rajagantham VK. The association between poor glycaemic control $\left(\mathrm{HbA}_{1 \mathrm{c}}\right.$ levels $\left.\geq 7 \%\right)$ and higher incidence of diabetic retinopathy in small group of type 2 diabetes mellitus patients, attending Mahatma Gandhi Memorial Government Hospital, Trichy. J. Evolution Med. Dent. Sci. 2017;6(66):4761-4764, DOI: $10.14260 /$ Jemds/2017/1031

\section{BACKGROUND}

Diabetes mellitus (DM) is a common metabolic disorder world-wide. Worldwide prevalence of Diabetes Mellitus has risen steeply over the past two decades and based on the current trends, about 438 million individuals will have Diabetes Mellitus by 2030.[1]

The Microvascular complications of Diabetes Mellitus, result from chronic hyperglycaemia and the effect of Advanced Glycation End (AGE) products. Blindness is due to progressive Diabetic Retinopathy (DR) and Macular Oedema.[1]

Financial or Other, Competing Interest: None.

Submission 14-07-2017, Peer Review 07-08-2017,

Acceptance 12-08-2017, Published 17-08-2017.

Corresponding Author:

Dr. Vijayalakshmi Sigamani,

\#1893, Vasantha Colony,

Anna Nagar, Chennai-600040.

E-mail:vijisigah@yahoo.com

DOI: $10.14260 /$ jemds $/ 2017 / 1031$

\section{(c) $(1)(5)$}

Duration of Diabetes Mellitus has been proved to have direct causal link with occurrence of these Microvascular Complications, especially the Diabetic Retinopathy.[1] Longterm poor Control of Blood Glucose level, as an independent causal factor, for these complications, is still under study and there have been numerous Randomised clinical trials, which have showed that a reduction in chronic hyperglycaemia, prevents or delays the microvascular complications.

Of all the variables which measure the control of Blood Glucose, Glycated Haemoglobin or $\mathrm{HbA}_{1 \mathrm{c}}$, is a very good predictor of Microvascular complications including Diabetic Retinopathy.

Both the 'Diabetes Complications and Control Trial (DCCT)' and 'UK Prospective Diabetes Study (UKPDS)' have showed that each $10 \%$ reduction in average blood glucose levels - as reflected by glycosylated haemoglobin (HbA1c) lowers the risk of developing Diabetic Retinopathy by roughly $60 \%$, and lowers by $43 \%$ the risk of pre-existing diabetic retinopathy getting worse.[2] The proposed HbA1c threshold of $48 \mathrm{mmol} / \mathrm{mol}$ (6.5\%) from American Diabetes 
Association produced comparable accuracy for identifying moderate/severe retinopathy.[3]

The optimal cut-off points for detecting mild and moderate retinopathy were $6.6 \%$. The prevalence of mild and moderate retinopathy was $<1 \%$ below the optimal cutoff points. [4]

However, there is no specific value of HbA1c, below which the Diabetic complications can be eliminated. [5]

Hence, this study was conducted to verify the association between the duration of Diabetes Mellitus and Glycaemic control with respect to the onset of Diabetic Retinopathy.

\section{MATERIALS AND METHODS}

It is a case-control study, with total of 60 subjects. Cases were Type 2 DM Patients with Diabetic Retinopathy (DR) and Controls were Type 2 DM without signs suggestive of DR.

Type 2 Diabetes (the Adult-onset Diabetes) includes subjects with Insulin Resistance and they have Relative (not absolute) Insulin Deficiency with an initial Plasma Glucose values exceeded the Diagnostic cut-off values as fixed by the Experts (FPG $\geq 126 \mathrm{mg} / \mathrm{dL}$; PPBG $\geq 200 \mathrm{mg} / \mathrm{dL}$ ).

Diabetic Retinopathy is defined and classified based on the WESDR and the ETDRS Criteria. There are 5 stages. First is "no apparent retinopathy" in which there are no fundal changes. Second stage is "mild Non-Proliferative Retinopathy" (NPDR). This stage has few microaneurysms. Third stage is "Moderate NPDR" which has microaneurysms, Intra-Retinal Haemorrhages and Venous Beadings that are not severe. "Severe NPDR", the fourth stage, is the key level to identify. Diagnosis of severe NPDR is by the $4: 2: 1$ rule of ETDRS. If Haemorrhages are there in all four quadrants, then severe NPDR is present. If two quadrants or more have Venous Beading (VB), Severe NPDR is present. If one or more quadrants have Intraretinal Microvascular Abnormalities (IRMA), then by definition severe NPDR is present. The last stage is "Proliferative Diabetic Retinopathy" (PDR). It is characterised by Neovascularisation of the disc, Neovascularisation of Retina, Neovascularisation of the Iris, Neovascularisation of the Angle, Vitreous Haemorrhage or Tractional Retinal Detachment. With respect to macular oedema, it is either present or absent. If present, then it is further classified as mild, moderate and severe based on distance of exudates and thickening from fovea.

Cases and Controls were selected based on a SelfAnswered Research Questionnaire and after doing a fundal examination. below.

Sample Size was calculated using the formula given $\mathrm{n}=\left(\mathrm{Z}_{\alpha / 2}+\mathrm{Z}_{\beta}\right)^{2 *}\left(\mathrm{p}_{1}\left(1-\mathrm{p}_{1}\right)+\mathrm{p}_{2}\left(1-\mathrm{p}_{2}\right)\right) /\left(\mathrm{p}_{1}-\mathrm{p}_{2}\right)^{2}$ where $\mathrm{Z}_{\alpha / 2}$ is the critical value of the Normal distribution at $\alpha / 2$ (for a confidence level of $95 \%, \alpha$ is 0.05 and the critical value is 1.96),

$\mathrm{Z}_{\beta}$ is the critical value of the Normal distribution at $\beta$ (for a power of $80 \%, \beta$ is 0.2 and the critical value is 0.84 ) and

$\mathrm{p}_{1}$ and $\mathrm{p}_{2}$ are the expected sample proportions of the two groups. (Kept at $70 \%$ and $40 \%$ respectively based on previous literatures).

\section{Exclusion Criteria}

Pre-existing Retinal Diseases including Hypertensive Retinopathy and Congenital diseases.
Pre-existing Renal Diseases.

\section{Inclusion Criteria}

Type 2 Diabetes Mellitus Patients attending MGM GH Diabetic OPD.

A total of 31 cases and 29 control subjects were included in this study. Poor Glycaemic Control ( $\mathrm{HbA}_{1 \mathrm{c}}$ levels $\geq 7 \%$ ) was taken as Exposure Factor. $\mathrm{HbA}_{1 \mathrm{c}}$ levels was assayed in every subject using HemoCue Analyser using Column Cartridges (Boronate Affinity Chromatography).

\section{Methods}

The Study Design is approved by the Institutional Ethical Committee Board. Subjects were selected based on selfwritten research questionnaire and informed consent was obtained.

General Examination was done and baseline demographics recorded.

Fasting and Post-Prandial Blood samples were collected from the Subjects. Fasting and Post-Prandial blood sugar, Lipid Profile, Urea, Creatinine was assayed using the standard kit methods using Fully Automated Analyser (EM360 Floor Model). In Whole Blood Capillary samples, $\mathrm{HbA}_{1 \mathrm{c}}$ levels were measured immediately using pre-filled column Cartridges, provided by the Manufacturer in HemoCue Analyser, by Boronate Affinity Chromatography method.

All patients underwent Ophthalmic Examination and Colour Photographs of Diseased Retina of subjects with Retinopathy was also taken.

\section{Statistics}

Data was collected and the results were compared using Odd's Ratio Calculator using MedCalc Easy - to - useStatistical Software. At 95\% CI, Confidence levels at a p value of 0.05 was derived for the Odd's of the $2 \times 2$ Contingency Table and Significance of Association was interpreted.

The tables below give the demographic details of the present study and also the statistical comparisons and inferences. The results and statistics are given in the tables below.

\section{RESULTS}

\begin{tabular}{|c|c|}
\hline Name of Variables & Mean \pm S.D. \\
\hline Age of Participants & $59.85 \pm 9.125$ \\
\hline Systolic Blood Pressure & $129.833 \pm 12.418$ \\
\hline Diastolic Blood Pressure & $85.166 \pm 11.859$ \\
\hline Fasting Blood Glucose & $136.566 \pm 40.472$ \\
\hline Post-prandial Blood Glucose & $224.916 \pm 70.99$ \\
\hline Urea & $32.216 \pm 11.99$ \\
\hline Creatinine & $1 \pm 0.415$ \\
\hline Total Cholesterol & $212.88 \pm 41.89$ \\
\hline Triglycerides & $201.98 \pm 109.14$ \\
\hline HDL & $37.766 \pm 4.774$ \\
\hline VLDL & $40.37 \pm 21.80$ \\
\hline LDL & $134.746 \pm 42.69$ \\
\hline HbA1C & $7.96 \pm 1.304$ \\
\hline $\begin{array}{c}\text { Table 1. Baseline Demographics } \\
\text { of All Subjects Included in the Study }\end{array}$
\end{tabular}




\begin{tabular}{|c|c|c|c|c|}
\hline $\begin{array}{l}\text { Sl. } \\
\text { No. }\end{array}$ & $\begin{array}{c}\text { Age } \\
\text { Split-up's }\end{array}$ & $\begin{array}{c}\text { Diabetes } \\
\text { Duration } \\
<10 \text { years }\end{array}$ & $\begin{array}{c}\text { Diabetes } \\
\text { Duration } \\
>10 \text { years }\end{array}$ & $\begin{array}{c}\text { Chi Square } \\
\text { Test \& } \\
\text { Statistical } \\
\text { Significance } \\
\end{array}$ \\
\hline 1 & $\begin{array}{c}20-40 \\
\text { years }\end{array}$ & 1 & 2 & \multirow{3}{*}{$\begin{array}{c}0.61539 \text { is } \\
\text { Chi square } \\
\text { value } \\
\text { Which is } \\
\text { Not significant. }\end{array}$} \\
\hline 2 & $\begin{array}{l}40-60 \\
\text { years }\end{array}$ & 13 & 14 & \\
\hline 3 & $\begin{array}{c}60-80 \\
\text { years }\end{array}$ & 16 & 14 & \\
\hline
\end{tabular}

\begin{tabular}{|c|c|c|c|c|}
\hline $\begin{array}{l}\text { Sl. } \\
\text { No. }\end{array}$ & Sex & $\begin{array}{l}\text { Diabetes } \\
\text { Duration } \\
<10 \text { yrs. }\end{array}$ & $\begin{array}{l}\text { Diabetes } \\
\text { Duration } \\
>10 \text { yrs. }\end{array}$ & $\begin{array}{c}\text { Chi Square } \\
\text { Test \& } \\
\text { Statistical } \\
\text { Significance }\end{array}$ \\
\hline 1 & Males & 12 & 16 & \multirow{2}{*}{$\begin{array}{c}0.3006 \text { is } \\
\text { Chi square value } \\
\text { Which is } \\
\text { Not significant. }\end{array}$} \\
\hline 2 & Females & 18 & 14 & \\
\hline & among & 00 & C Di & $\begin{array}{l}\text { ution } \\
\text { ignificance }\end{array}$ \\
\hline
\end{tabular}

\begin{tabular}{|c|c|c|c|}
\hline & $\begin{array}{c}\text { Presence of } \\
\text { Retinopathy }\end{array}$ & $\begin{array}{c}\text { Absence of } \\
\text { Retinopathy }\end{array}$ & $\begin{array}{c}\text { Odds Ratio \& } \\
\text { Statistical Inference }\end{array}$ \\
\hline $\begin{array}{c}\text { HbA1C } \\
\text { Levels } \\
>7\end{array}$ & 25 & 18 & $\begin{array}{c}\text { Odds Ratio of } 2.75 \\
(>1 \text { at p-value 0.05) } \\
\text { strongly predicts } \\
\text { association between } \\
\text { Glycaemic Control in } \\
\text { subjects \& } \\
\text { Retinopathy. }\end{array}$ \\
$\begin{array}{c}\text { HbA1C } \\
\begin{array}{c}\text { Levels } \\
>7\end{array}\end{array}$ & 6 & 11 & $\begin{array}{c}\text { Absent } \\
\text { Table 4. Odds Ratio to test the Association between }\end{array}$ \\
Control of Diabetes Mellitus and Diabetic \\
Retinopathy in all Subjects. $n=60$
\end{tabular}

For the given data of Odds, at the 95\% Confidence level, the $\mathrm{CI}$ falls between $1.16-8.775$. This value does not include 1 and hence the above data is Significant at p-value of 0.05 .

\section{DISCUSSION}

Diabetic Retinopathy is the major cause of Blindness across the World among patients in working age.[6]

In the present study, the results and statistics show that there is a significant association in onset of Diabetic Retinopathy and poor Glycaemic Control (Odd's Ratio of 2.75 at $95 \% \mathrm{CI} / \mathrm{p}$-value of 0.05 ).

The present study results are similar to many earlier studies.

A valid mention would be the CURES Study, which was conducted in the urban areas of the Chennai City. In that study, it was concluded that the risk of Diabetic Retinopathy increases by 1.89 fold for every 5 years duration and by 1.7 fold for every $2 \%$ rise in $\mathrm{HbA}_{1 \mathrm{c}}$ levels. ${ }^{[7]}$

Duration of diabetes is already a well-proved independent causal factor for occurrence of the Diabetic Retinopathy and also fast progression to Proliferative Retinopathy. ${ }^{[8]}$

In a Chinese study done in 2002, the lead Researcher D.P. Liu and his colleagues have concluded that the patients who developed Retinopathy among the 2131 patients with type 2 diabetes included in the study, had duration of diabetes $(\mathrm{OR}=$ 1.8; $\mathrm{P}=0.001)$ and albumin excretion rate $(\mathrm{OR}=1.5 ; \mathrm{P}=$
0.019) as most important independent risk factors for retinopathy.[9]

Nathan et al, in his study has concluded that duration was the most powerful determinant, with a fourfold increase in prevalence of retinopathy in those whose duration of disease exceeded 10 years.[10]

With duration being accepted as an independent risk factor for the long-term complications, the role of glycaemic control is still not clearly confirmed as an independent risk factor.

$\mathrm{HbA}_{1 \mathrm{c}}$ levels in blood, actually integrate the summary of circadian variations of the blood glucose levels in the preceding 2-3 months period, which is actually the lifespan of Red Blood Cells.[11]

Various Literatures say that there is clear and significant reduction in occurrence and progression of Diabetic Microangiopathies by tight glycaemic control.[12]

However, in 3 large epidemiological studies, it is concluded that there is no significant association between Glycaemic control and the severity of Diabetic Complications. ${ }^{[12,13,14]}$

But, in a study conducted in 2004 and published in BMJ Ophthalmology, Manavit et al concluded that $\mathrm{HbA}_{1 \mathrm{C}}$ was significantly higher in patients with PDR (mean $=10.5 \%$ ) than in patients with no signs of retinopathy (mean $=9.5 \%$ ) which indirectly says that reduction of $\mathrm{HbA}_{1 \mathrm{c}}$ or tight Glycaemic control may check the rate of progression of Diabetic Retinopathy.[15]

The DCCT/EDIC study also clearly says that the prior intensive treatment and lowering of mean $\mathrm{HbA}_{1 c}$ during the DCCT period continue to exert a beneficial effect during the EDIC study on Retinopathy for at least 7 years and on Nephropathy for at least 7 - 8 years.[16]

\section{CONCLUSION}

In the present study, it is concluded that there is significant association between the Poor Glycaemic Control of Diabetes Mellitus and higher incidence of Diabetic Retinopathy.

Our study is limited by the fact that the results and conclusions cannot be extrapolated to the whole population as the sample size reflects only the population of Diabetic Patients attending the OPD of MGM GH. Also, Causal associations are best studied using Cohort populations and the present study is a case-control study. The present study does not include other biomarkers like AGEs, etc. A special mention about the study done by Geneth/Saul and others, which has concluded that the assays of skin collagen, furosine (Glycated Collagen) and the AGEs, mainly the CML, indicate the risk of rate of progression of Diabetic Retinopathy over 10 years and Nephropathy over 9 to 10 years in subjects with Type 1 Diabetes Mellitus.[17]

In future, the same study can be designed as a cohort study and with considerable sample size. Also, Advanced Glycation End (AGE) products like Furosine/Carboxymethyllysine can be included and compared along with $\mathrm{HbA}_{1 \mathrm{c}}$ levels.

\section{ABBREVIATION}

DM- Diabetes Mellitus; DR- Diabetic Retinopathy; AGEAdvanced Glycation End Products. 


\section{REFERENCES}

[1] Fauci AS, Braunwald E, Kasper DL, et al. Harrison's principles of internal medicine. 17th edn. New York: McGraw Hill 2008.

[2] Sanjay S, Chin YC, Sun Y, et al. Awareness of $\mathrm{HbA}_{1 \mathrm{c}}$ and its relationship with diabetic retinopathy among adult diabetic patients attending a tertiary ophthalmic center. Diabetes Care 2013;36(1):e1.

[3] Cho NH, Kim TH, Woo SJ, et al. Optimal HbA1c cut-off for detecting diabetic retinopathy. Acta Diabetologica 2013;50(6):837-42.

[4] Sabanayagam C, Liew G, Tai ES, et al. Relationship between glycated haemoglobin and microvascular complications: is there a natural cut-off point for the diagnosis of diabetes? Diabetologia 2009;52(7):127989.

[5] Tietz NW, Burtis CA, Ashwood ER, et al. Tietz textbook of clinical chemistry and molecular diagnostics. $4^{\text {th }}$ edn. St. Louis, Mo: Elsevier Saunders 2006:2097-152.

[6] Kollias AN, Ulbig MW. Diabetic retinopathy. Dtsch Arztebl International 2010;107(5):75-84.

[7] Rema M, Premkumar S, Anitha B, et al. Prevalence of diabetic retinopathy in urban India: the Chennai urban rural epidemiology study (CURES) eye study, I. Investigative ophthalmology \& visual science 2005;46(7):2328-33.

[8] Porta M, Sjoelie AK, Chaturvedi N, et al. Risk factors for progression to proliferative diabetic retinopathy in the EURODIAB prospective complications study. Diabetologia 2001;44(12):2203-9.

[9] Liu DP, Molyneaux L, Chua E, et al. Retinopathy in a Chinese population with type 2 diabetes: factors affecting the presence of this complication at diagnosis of diabetes. Diabetes Research and Clinical Practice 2002;56(2):125-31.
[10] Nathan DM, Singer DE, Godine JE, et al. Retinopathy in older type 2 diabetics. Association with glucose control. Diabetes 1986;35(7):797-801.

[11] Longo-Mbenza B, Muaka MM, Mbenza G, et al. Risk factors of poor control of $\mathrm{HbA1c}$ and diabetic retinopathy: paradox with insulin therapy and high values of HDL in African diabetic patients. Int J Diabetes \& Metabolism 2008;16:69-78.

[12] Group TAC. Intensive blood glucose control and vascular outcomes in patients with type 2 diabetes. New England Journal of Medicine 2008;358(24):256072.

[13] Group TAtCCRiDS. Effects of Intensive glucose lowering in type 2 diabetes. New England Journal of Medicine 2008;358(24):2545-59.

[14] Duckworth W, Abraira C, Moritz T, et al. Glucose control and vascular complications in veterans with type 2 diabetes. New England Journal of Medicine 2009;360(2):129-39.

[15] Manaviat MR, Afkhami M, Shoja MR. Retinopathy and microalbuminuria in type 2 diabetic patients. BMC ophthalmology 2004;4(1):9.

[16] Aiello LP, DCCT/EDIC Research Group. Diabetic retinopathy and other ocular findings in the diabetes control and complications trial/epidemiology of diabetes interventions and complications study. Diabetes care 2014;37(1):17-23.

[17] Genuth S, Sun W, Cleary P, et al. Glycation and carboxymethyllysine levels in skin collagen predict the risk of future 10-year progression of diabetic retinopathy and nephropathy in the diabetes control and complications trial and epidemiology of diabetes interventions and complications participants with type 1 diabetes. Diabetes 2005;54(11):3103-11. 